\title{
Ricardian Theorem Reality; Assessment of Sino-Tanzania Trade 2015-2019
}

\author{
Nyagoga Lucy Michael \\ School of Economics, Zhejiang Gongshang University, Hangzhou, China \\ Email: nyagogalucy@gmail.com
}

How to cite this paper: Michael, N. L. (2021). Ricardian Theorem Reality; Assessment of Sino-Tanzania Trade 2015-2019. Open Journal of Social Sciences, 9, 448-457. https://doi.org/10.4236/jss.2021.94033

Received: April 2, 2021

Accepted: April 24, 2021

Published: April 27, 2021

Copyright $\odot 2021$ by author(s) and Scientific Research Publishing Inc. This work is licensed under the Creative Commons Attribution International License (CC BY 4.0).

http://creativecommons.org/licenses/by/4.0/

\begin{abstract}
China has suited a noteworthy economic partner position in African countries, specifically Tanzania. Consequently, this research is aiming at determining the reality of the Ricardian theorem of comparative advantage by assessing its applicability to $21^{\text {st }}$ Century International trade practice particularly the Sino-Tanzania bilateral trade from 2015 to 2019. To find out if Sino-Tanzania bilateral trade resembles the Ricardian theorem, the classical Balassa index (RCA), import and export intensity indexes were used to establish the revealed comparative advantage by-products between Tanzania and China in their bilateral trade. With the aid of International trade data obtained by the United National conference of Trade and Development (UNCTAD), (World Trade Organization) WTO and the Observatory of Economic Complexity (O.E.C.). The Balassa index, as well as import and export indexes, carried out some statistical tests grounding on both export and import merchandise trade (Standard International Trade Classification (SITC), Revision 3) related products; the study results established confirm the comparative advantage theory application in $21^{\text {st }}$ Century reality particularly in Sino-Tanzania bilateral trade in the timeline of 2015-2019 import-export trade.
\end{abstract}

\section{Keywords}

Law of Comparative Advantage, R.C.A, Sino-Tanzania Bilateral, Export-Import

\section{Introduction}

From the time when China struggled until she decided to abandon closed economy and alternativity pursued economic reforms in the 1970s with strategies such as fostering export as well as substitute imports, G.D.P. also grew in favor of the reforms to about 10 per cent annually, alongside, more than a quarter of the total population was saved from massive poverty (Moshi \& Mtui, 1970). Currently, 
China is growing superficially than anyone could imagine, due to that, she is an upper-middle-income earner level making away up to the world first economy as she is the second leading economy in recent years (World Bank, 2020a). Moreover, when China is in a higher rank, other countries are uplifted as well due to the trade and Investment generated out of China prosperity to developing countries like Tanzania (T.I.C, 2019). Sino-Tanzania bilateral relations can be traced back early to the era that Tanzania got independence and operated as a communist country in the 1960s to a mixed economy in later years from the 1980s (Moshi \& Mtui, 1970). For the most part, Sino-Tanzania bilateral relationship is somehow viewed as historical and uniquely political more than economical given the friendship ties between Tanzania and China is dated back from political ties involved (Pearson \& Meyer, 1974). Currently, the relationship is far advanced and economic oriented than prior decades, from the first President (Julius Kambarage Nyerere) to the late former President (John Magufuli) over thousands of treaties and business deals are made either Government oriented or individual based (Krugman \& Obstfeld, 2006). It is quite a sadness that with the rich resources that Tanzania has, she is experiencing a trade deficit with China over the years, as the trade volume between these two countries increases (Reuters, 2012), a trade deficit is getting worse because of the distinctive difference between trade volume and value (Pugel, 2005; Helpman, 2011). To demonstrate it, China's exports to Tanzania generate about $\$ 1.8$ Billion, the latter's exports earn $\$ 150$ million in 2018 alone (UNCTAD, 2021).

Furthermore, O.E.C report tells a different story on its 2018 annual report, according to the Observatory of Economic Complexity 2019 Data shows that in the year 2018 alone, China was the $3^{\text {rd }}$ export partner of Tanzania and the first import partner of about 299 Million \$ and 2.92 Billion \$ respectively (O.E.C, 2019). On the other hand, in 2016 alone, Tanzania's export to the Peoples Republic of China amounted to USD 144.59 million. China is Tanzania's prime import partner by volume of import while at the same time, Tanzania's import from the Peoples Republic of China amounted to USD 1.77 billion. For almost two years alone, Sino-Tanzania bilateral export-import trade has doubled, which shows that Sino-Tanzania bilateral trade is progressing at a reasonable figure as shown in figure (Figure 1 \& Figure 2) (T.I.C, 2019; O.E.C, 2019). Additionally, Despite the advantageous data indicating that Sino-Tanzania bilateral trade is progressing over the years, the question remains on the Balance of trade in Sino-Tanzania bilateral trade, asking if Sino-Tanzania bilateral trade is beneficial to both countries as it was stated in papers. David Ricardo's law of Comparative Advantage echoing that there is still room for two countries to have mutual benefit and gain from trade regardless of their efficiency and level of development if the country specifies production-based in the product that she has comparative advantage and exchange to get the products that they have a comparative disadvantage from other countries (Ricardo, 1817; Salvatore, 2016). This research is comprised of five main parts namely Introduction, literature review, methodol 


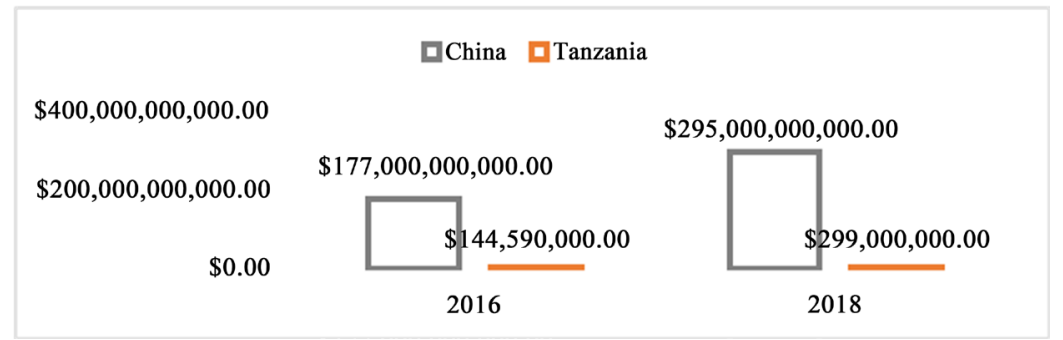

Figure 1. Sino-Tanzania export-import trade in year 2016 and 2018 (figure caption).
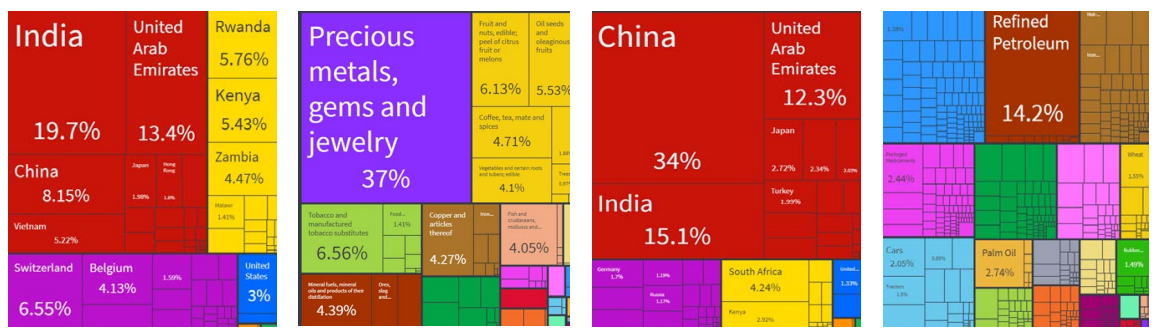

Figure 2. Tanzania import-export composition 2019 (figure caption).

ogy, results, and conclusion. The introduction part covers the background of Sino-Tanzania bilateral trade whereby it broadly explains Sino-Tanzania bilateral trade status from independence to currently, thereafter, the literature review provides a thorough review from previous related studies. Moreover, the methodology is the integral part showing ways through which the findings of the study were obtained while the result part describes the results obtained, conclusion part sums up the research and provide the possible solution towards Ricardian theorem Reality on Sino-Tanzania bilateral trade.

\section{Literature Review}

The Ricardian Theorem by David Ricardo (1817) states that the nation should produce goods that are more proficient and sell to other nations while buy goods from others that are less effective to likely being produced due to different factors related to production (Ricardo, 1817; Salvatore, 2016). The two nations will expand their production by broadening income and making their customers save money and use more for the two products by paying less (Hill, 2008; Chingarande et al., 2013). The Ricardian law has been endorsed significantly by Heckscher-Ohlin (Krugman \& Obstfeld, 2006), who offers a lot of proof, given the factor endowment idea (Hill, 2008; Salvatore, 2016). A nation is of Comparative Advantage on the off chance that it abuses the resources by utilizing them well as well as create a favorable environment for trade with other countries (Eifert et al., 2005). A similar view of a country as free trade exposes more influence worldwide by establishing international trade strategies which can support imports openness from others hence increase trade volume (Lancaster. 1994). Developing countries are suffering from the debts and trade deficits that comes in the name of trade because they cannot be competitive enough with their Agricultural and raw materials products with the giant machines that are im- 
ported from other nations (Hill. 2008), the Tourism, and mining industry has proven to grow rapidly in Tanzania but what they can bring is hardly enough to survive with for EAC countries (Mzumara et al., 2013). With the monetary escalation, poverty decrease, the foundation of common political qualities, and improving life standard but there are still areas of doubt as to whether International trade is a key factor for trade between EAC and the rest of the world (Mzumara et al., 2013). Reflecting on the potential twists in trade in general because of unfair trade boundaries, Mzumara in his studies mentioned that the burden lines on the regular for the R.T.A.s, which makes utilizing the R.C.A. relevant to measure International trade especially export-wise related to the adjustments in the local direction of trade to recognize any obvious failure in import exchange designs for the developing nations like Tanzania when engaging in trade with industrialized countries like China (Muchanyuri \& Mzumara, 2013).

Various studies have utilized the RCA index record to quantify and think about various areas of economies universally particularly International trade-related cases, however, few utilized export intensities using RCA whereas none have analyzed import intensity at all. Chingarande et al. (2013) utilized R.C.A. to research the similar Advantage of the East African Community (E.A.C.) their monetary implications in given sectors. It described that all particulars on each sector have R.C.A., in any case, in a couple of items and have very much performed monetarily. A study about Sino-India trade done by Batra and Khan inspected the structure of the Ricardian in China and India who compete to trade with Tanzania for over a decade and agreed that RCA is useful to test International trade between trading nations (Batra \& Khan, 2005), as it offers the areas or potentiality in each country, in addition to other things, there are likenesses in the result on their study (Batra \& Khan, 2005) with the analysis of this study apart from 10 years gap between these two kinds of research. In any case, there was no connection between the assembling areas in the Peoples Republic of China and India on the global market. Moreover, Mzumara et al. (2013) have utilized the Balassa R.C.A. list for Southern African Development Community part States and reasoned that all part of the SADC which includes 15 countries from the southern part of Africa have R.C.A too, however, there are slight differences from one area to the other; nonetheless, they have fewer items with a similar favorable position in the region. Uncovered Comparative Advantage Outlines Peoples Republic of China's change of its price strategy, which demonstrated the different tariffs according to the region, however, China is still a potential partner when it comes to Tanzania bilateral trade with other countries but the most part much each country gain from the trade has been a mystery of years (Mzumara et al, 2013).

\section{Methodology}

This paper used data from the United Nations Conference on Trade and Development Statistics Database (UNCTAD) to calculate Tanzania and China's International Trade (export-import) data from 2015 and 2019 and analyse the 
comparative Advantage of the SITC (Standard International Trade Classification) Revision 3 by using RCA, import and export indexes. Subsequently, It used the export and import data to find the comparative advantage of Tanzania and China as well as import and export intensity among these trading countries to determine the trade length of both import and from and to each other. To determine whether Tanzania and China have a comparative advantage on the specified goods/products and time in conformity to the Law of Comparative advantage, the study employed the RCA index (Revealed Comparative Advantage) pioneered by Balassa 1965, Balassa index also known as (RCA) Revealed Comparative Advantage index is the calculation based on trade flows, the underlying assumption of RCA is that trade flows between trading countries can "reveal" country's comparative advantages between or among certain trading countries with respect to good/service in a given time of period.To determine comparative advantage trade flows entails what goods/services certain country can trade more to the rest of world hence identify country's competitiveness as well as efficiency in specified goods/services. Over the years, Balassa index has been a productive way to calculate country's comparative advantage in certain goods/services (Mzumara et al., 2013). While evaluating the import and export volume as well as the gain of trade in exchange for Sino-Tanzania bilateral trade as Ricardian theory suggested, the study employed importation and exportation tensity too. The result establishes where the country has a comparative advantage or disadvantage in each product/good as well as reveals the import and export intensity, If the results are either $=1$ or $<1$ country $i$ is not enjoying an RCA in commodity $\mathrm{k}$. while the index with a higher than 1 result implies that a country has an RCA in commodity $k$, the country $i$ low import to export from or to the country $j$. when the result is greater than 1 country, $i$ has higher RCA in commodity $\mathrm{k}$, and country $i$ has high import or export intensity from country $j$.

$$
R C A_{i k}=(X i k / X i) /(X k / X)
$$

$X i k=$ exports of commodity $k$ by country $I, X i=$ country $i$ s total export, $X k=$ total world trade in commodity, $X=$ total world trade.

$$
i m p i j=(M i j / M i) /(X j / X w-X i) \text { and } e x i j=(X i j / X i) /(M j / M w-M i)
$$

$M i j=$ total imports of country $i$ from country j, $M i=$ total imports of country $i, X i, X j=$ total exports of $i$ and $j, X W=$ total world trade, $X i j=$ total exports of country $i$ to country $j, X i=$ total exports of country $i, M i, M j=$ total imports of $i$ and $j, M w=$ total world trade.

\section{Results}

Revealed comparative Advantage depicted several crucial issues about both Tanzania and China exports by using data from UNCTAD (United Nations Conference of Trade and Development) and WTO International trade statistics, as well as import-export data combined to determine import and export intensity between these two trading countries. The analysis uncovered that Tanzania 
has a significant comparative advantage in agricultural and resources intensive related products such as cocoa, gold, hides and skin, fibres vegetables and textile materials, and food products like fish, spices as well as cereal meal and flour goods with average RCA from 10 to 202 in the length of 5 years (2015-2019). Whereas China has a comparative disadvantage on those products (Agricultural and resources intensive), China has the comparative advantage in the manufactured and technology-intensive product instead, with high RCA from 2.8 to 5.1 in products like clothing accessories, telecommunication, pottery, lighting apparatus, baby sports, tulles, and fabrics from 2015-2019 as shown in Table $1 \&$ Table 2.

Table 1. RCA Index; China Top RCA by-products 2015-2019 (Table caption is indispensable).

\begin{tabular}{cccc}
\hline \multirow{2}{*}{ Product } & \multicolumn{2}{c}{ China's RCA 2015-2019 } \\
\cline { 2 - 3 } Fabrics, woven, of man-made fabrics & Average & Maximum & Minimum \\
Tulles, trimmings, lace, ribbons \& small wares & 2.8 & 3.9 & 3.4 \\
Made-up articles of textile materials & 3.4 & 3.04 & 3.62 \\
Pottery & 5.1 & 3.48 & 4.82 \\
Automatic data processing machines & 3.1 & 5.09 & 3.14 \\
Telecommunication equipment \& parts & 2.9 & 3.24 & 2.8 \\
Lighting fixtures \& fittings & 4.4 & 3.09 & 4.32 \\
Women's clothing, of textile, knitted or crocheted & 3.1 & 4.47 & 2.9 \\
Clothing accessories of textile fabrics & 3.3 & 3.39 & 3.29 \\
Baby carriages, toys, games \& sporting goods & 3.7 & 3.36 & 3.4 \\
\hline
\end{tabular}

Source: https://unctadstat.unctad.org/wds/TableViewer/tableView.aspx?ReportId=157975 (Table footnote is dispensable).

Table 2. RCA Index; Tanzania Top RCA by-products 2015-2019 (Table caption is indispensable).

\begin{tabular}{cccc}
\hline \multirow{2}{*}{ Product } & \multicolumn{2}{c}{ Tanzania's RCA 2015-2019 } \\
\cline { 2 - 3 } Cocoa & Average & Maximum & Minimum \\
Crude Vegetable materials & 11.5 & 12.79 & 9.2 \\
Fish, aqua. invertebrates, prepared, preserved & 32.1 & 66.45 & 0.44 \\
Fruit, preserved, and fruit preparations (no juice) & 12.1 & 28.88 & 10.59 \\
Hides and skins (except furskins) & 145.2 & 18.49 & 10.17 \\
Other cereal meals and flour & 43.6 & 63.93 & 4.13 \\
Spices & 15.1 & 16 & 14.68 \\
Synthetic fibres suitable for spinning & 37.8 & 44.88 & 27.56 \\
Vegetable textile fibres, not spun; waste of them & 202.2 & 492.18 & 39.23 \\
Gold, non-monetary (excluding gold ores and & 13.5 & 13.86 & 10.48 \\
concentrates) & & & 82.08 \\
\hline
\end{tabular}

Source: https://unctadstat.unctad.org/wds/TableViewer/tableView.aspx?ReportId=157975 (Table footnote is dispensable). 
According to this study, Tanzania exported about an average of $\$ 5.64$ billion to the World annually from 2015-2019, meanwhile Tanzania export to China is only $6 \%$ which is equal to the average of $\$ 338.4$ million years, while most of the exported products include, raw tobacco, precious metal, coffee, and many other raw materials. Alternatively, Tanzania imported about an average of \$11.7 Billion from all over the world annually in 5 years, yet she imported about $34 \%$ from China which is equal to an average of $\$ 3.9$ billion annually and the main products imported includes refined petroleum, cars, palm oil and wheat as well as medium machines like food and agricultural products processors. The result is not fitting for a country like Tanzania, which has trade deficits as it is supposed to increase and specialize more in export products while improving the internal market, however, imports doubled from export which is why the trade deficit is inevitable. Tanzania grasps the maximum opportunities in resources intensive related products as they have the highest R.C.A. than any other product or commodities due to her resource's endowment although she has more volume rather than value compared to what China exports to Tanzania as shown in Table 1 \& Table 2. Nevertheless, Tanzania chooses to target the market such as resource-intensive which is less competitive at the global market as the analysis shows that it only accounts for $8.9 \%$ of the world total trade of all products. Hence, more opportunity for Tanzania to attain a much higher comparative advantage but does not necessarily indicate many benefits from Sino-Tanzania bilateral trade as shown in Table 3 \& Table 4.

Ultimately, the quest to whether the law of comparative advantage is applicable in $21^{\text {st }}$ International trade reality using UNCTAD International trade statistics as well as RCA import and export intensity indexes basing on Sino-Tanzania bilateral Trade is answered. The answer corresponding to the analysis is Yes, the Ricardian theory applies to today's reality especially International trade wise. However, the essence of how the assumption of the theory is still relevant are

Table 3. Exporation Intesity Index (Table caption is indispensable).

\begin{tabular}{cccc}
\hline & \multicolumn{3}{c}{ Exportation intensity Results } \\
\cline { 2 - 4 } Country & $\boldsymbol{X}_{i j} / \boldsymbol{X}_{\boldsymbol{i}}$ & $\boldsymbol{M}_{j} / \boldsymbol{M}_{\boldsymbol{w}}-\boldsymbol{M}_{\boldsymbol{i}}$ & $\mathrm{ex}_{i j}$ \\
\hline China & 0.002 & 0.0003 & 6.7 \\
Tanzania & 0.8 & 0.07 & 11.4 \\
\hline
\end{tabular}

Source: https://unctadstat.unctad.org/wds/TableViewer/tableView.aspx?ReportId=157975 (Table footnote is dispensable).

Table 4. Imporation Intensity Index (Table caption is indispensable).

\begin{tabular}{cccc}
\hline \multirow{2}{*}{ Country } & \multicolumn{3}{c}{ Importation Intensity Results } \\
\cline { 2 - 4 } & $\boldsymbol{M}_{\boldsymbol{i j} / \boldsymbol{M}_{\boldsymbol{i}}}$ & $\boldsymbol{M}_{j} / \boldsymbol{M}_{\boldsymbol{W}}-\boldsymbol{M}_{\boldsymbol{i}}$ & $\boldsymbol{i m \boldsymbol { p } _ { i j }}$ \\
\hline China & 0.0008 & 0.065 & 0.013 \\
Tanzania & 0.25 & 0.065 & 3.18 \\
\hline
\end{tabular}

Source: https://unctadstat.unctad.org/wds/TableViewer/tableView.aspx?ReportId=157975 (Table footnote is dispensable). 
redundant since having Comparative advantage or disadvantage in certain products does not necessarily mean that the country is either gaining from Trade. Unlike most of the previous studies this research is up to date 2015-2019 in contrast to previous studies that have ranged from 1990s to 2013, in addition to previous studies this research has spotted new trend of Sino-Tanzania trade which accounts for both inter and intra sector associated trade among these trading countries, however, intra trade is increasing due to China tendency of re-exporting value-added version of imported products from Tanzania. Although inter sectoral trade has been dominant for years among these trading countries (Tanzania and China), intra sectoral trade is raising rapidly in Sino-Tanzania bilateral trade especially in complementary goods like Gold and clothing acceserories shown in Table 1 and Table 2. To show this, the two trading countries (Tanzania and China) have been gaining from Trade, yet, the mutually beneficial part between these two countries is in dilemma given the essence that China gain more than Tanzania in the trade regardless of the data showing that China has a comparative disadvantage in resources-intensive products, which according to Tanzania Investment Centre China export at least $50 \%$ of these kinds of products to Tanzania for over a decade (T.I.C, 2019). Nevertheless, the study conducted data and analyses findings from interval of 5 years from 2015-2019 because these two years count on the progress made by Tanzania and China collectively as well as independently which boosts the trade among them. The beginning on new leadership of President Magufuli who revisited the mining and infrastructure sector dealings that Tanzania had with China for decades in 2015 hence trade deficit decreases by 15\% upon the third Quarter of 2015 thus elucidates the mutual beneficial trade of Sino-Tanzania bilateral trade obtained by numerous negotiations that these two trading countries had to convene and revise terms of their trade (World Bank, 2020a, 2020b). Among others, year 2019 Tanzania was officially announced as a low middle-income earner which alter the dynamic of trade as Tanzania announces Industrialization policy (T.I.C, 2019). Therefore, 2015 and 2019 are most dynamic years of Tanzania which ignite the sense of mutual beneficial trade as suggested by Ricardian Theorem.

\section{Conclusion}

This paper calls into question the International trade reality convergence to the Classical trade theorem, particularly the Ricardian Theorem. Meanwhile, the findings indicate the applicability of the Law of Comparative Advantage in a case study of Sino-Tanzania bilateral Trade by looking at their respective revealed comparative advantage as well as export and import intensity between and among these two trading countries. Various commodities such as agricultural and manufactured were put into test by using SITC commodity level to determine specialization and gain from trade as an outcome of trade (import-export) exchange, using export data from UNCTAD, WTO and O.E.C Database to examine the comparative Advantage and trade intensity from the year 2015-2019. The find- 
ings confirm that the law of comparative advantage applies to the Sino-Tanzania trade because Tanzania has a comparative advantage in resources-intensive products and China in Technology-intensive products, therefore they can exchange. However, few assumptions do not fit in the 21st International trade world. Moreover, Sino-Tanzania bilateral trade demonstrated that China gains more than Tanzania due to the analysis that indicates the trade deficit for Tanzania but trade surplus for China in the cause of trade because China re-export most of the products back to Tanzania with value-addition. Therefore, there is a need for Tanzania to add value to their agricultural products before exporting them to China, the best way is to encourage the manufacturing and processing Industry more so that Tanzania can gain more from trade as suggested by the Ricardian Theorem.

\section{Conflicts of Interest}

The author declares no conflicts of interest regarding the publication of this paper.

\section{References}

Batra, A., \& Khan, Z. (2005). Revealed Comparative Advantage: An Analysis for India and the Peoples Republic of China: Indian Council for Thesis on International Economic Relations. Working Thesis No. 168, New Delhi: India Habitat Centre.

Chingarande, A., Mzumara, M., \& Karambakuwa, R (2013). Comparative Advantage and Economic Performance of East African Community (E.A.C.) Member States. Journal of Economics, 4, 39-46. https://doi.org/10.1080/09765239.2013.11884963

Eifert, B., Gelb, A., \& Ramachandran, V. (2005). Business Environment and Comparative Advantage in Africa: Evidence from the Investment Climate Data. Örebro: Centre for Global Development. https://doi.org/10.2139/ssrn.1112857

Helpman, E. (2011). Understanding Global Trade. Cambridge, MA; London: Harvard University Press. https://doi.org/10.4159/harvard.9780674061019 https://www.amazon.com/Understanding-Global-Export-importtrade-Elhanan-Helpm an/dp/0674060784

Hill, C. W. (2008). International Trade Theory (6th ed., pp. 44-106). New York, NY; Beijing: McGraw-Hill and Posts \& Telecom Press.

Krugman, P. R., \& Obstfeld, M. (2006). International Economics: Theory and policy (7th ed., pp. 4-205.). Singapore: Pearson Education Asia Ltd.

Lancaster, K. (1994). Modern Consumer Theory. Cheltenham: Edward Elgar Publishing. https://www.amazon.com/Modern-Consumer-Theory-Kelvin-Lancaster/dp/185278384 $\underline{2}$

Moshi, H. P. B., \& Mtui, J. M. (1970). Scoping Studies on the People's Republic of ChinaAfrica Economic Relations: The Case of Tanzania. https://idl-bnc-idrc.dspacedirect.org/handle/10625/38582

Muchanyuri, B., \& Mzumara, M. (2013). Inter-Sectoral Comparative Advantage of Tanzania and Impact on International Purchasing. Greener Journal of Business and Management Studies, 3, 361-368. https://doi.org/10.15580/GJBMS.2013.8.102913937

Mzumara, M., Chingarande, A., \& Karambakuwa, R. (2012). An Analysis of the Revealed 
Comparative Advantage in Southern African. Journal of Sustainable Development in Africa, 14, 50-74.

O. E. C. (Observatory of Economic Complexity) (2019). Tanzania (T.Z.A.) Exports, Imports, and Trade Partners. https://oec.world/en/profile/country/tza

Pearson, S. R., \& Meyer, R. K. (1974). Comparative Advantage among African Coffee Producers. American Journal of Agricultural Economics, 56, 310-313. https://doi.org/10.2307/1238761

Pugel, A. T. (2005). International Trade (12th ed., pp. 17-149). Beijing: McGraw-Hill Education (Asia Co.) \& Peoples Republic of China Renmin University Press.

Reuters (2012). Tanzania trade Deficit Double Due to Oil Demand. https://ewn.co.za/Topic/Bank-of-Tanzania

Ricardo, D. (1817). On the Principles of Political Economy and Taxation. https://www.marxists.org/reference/subject/economics/ricardo/tax/index.htm

Salvatore, D. (2016). International Economics (12th ed.). Hoboken, NJ: Wiley. https://www.academia.edu/31514190/Salvatore d international economics

T.I.C. (Tanzania Investment Centre) (2019). Tanzania-Peoples Republic of China Relations Have Continued to Grow over the Years.

https://www.ippmedia.com/en/editorial/tanzania-PeoplesRepublicofChina-relations-ha ve-continued-grow-over-years

United Nations Conference on Trade and Development (UNCTAD) (2021). International Trade; Commodities; Urban, Rural \& Regional Development.

https://unctadstat.unctad.org/wds/ReportFolders/reportFolders.aspx

World Bank (2020a). China Economic Overview.

https://www.worldbank.org/en/country/china/overview

World Bank (2020b). Tanzania Economic Overview.

https://www.worldbank.org/en/country/tanzania/overview 